\title{
Peran Lembaga Adat Donggo (Lasdo) dalam Menyelesaikan Tindak Pidana Untuk Ius Constituendum
}

\author{
Suherman $^{1}$, Ady Irawan ${ }^{2}$ \\ ${ }^{1,2}$ STKIP Taman Siswa Bima \\ 2adyirawan652@gmail.com
}

\begin{abstract}
ABSTRAK
Tujuan dari penelitian ini adalah untuk mendeskripsikan : 1) peranan Lembaga Adat Donggo (Lasdo) dalam menyelesaikan suatu tindak pidana; 2) tindak pidana apa saja yang dapat diselesaikan melalui Lembaga Adat Donggo (Lasdo) di Kecamatan Donggo, dan 3) sinergisitas antara Lembaga Adat Donggo Lasdo dengan aparat kepolisian setempat dalam menangani tindak pidana. Jenis penelitian ini adalah penelitian yuridis empiris dengan menggunakan metode kualitatif bersifat deskriptif. Teknik pengumpulan data meliputi wawancara, perekaman, dan catat. Subyek penelitian yakni Ketua Lembaga Adat Lasdo, tokoh masyarakat, dan penegak hukum setempat. Hasil penelitian menunjukan bahwa, 1) Peranan Lembaga Adat Donggo (LASDO) dalam menyelesaikan tindak pidana di Kecamatan Donggo Kabupaten Bima sangat strategis. Peran itu terkristalisasi dari diberikan kewenangan LASDO dalam menetapkan jenis sanksi pidana (strafsort), bobot sanksi (strafmaat), serta pelaksanaan/eksekusi pidana (strafmodus) bagi pelaku tindak pidana. 2) Bahwa Lembaga adat dan Syari'at Donggo (LASDO) memiliki peranan dalam menyelesaikan tindak pidana yang terjadi di masyarakat Donggo, baik yang bersifat ringan hingga yang bersifat berat. 3) Sinergisitas antara Lembaga Adat LASDO dan aparat kepolisian setempat dalam menangani tindak pidana adalah berdasar asas saling menghormati dan menghargai serta asas musyawarah mufakat. Pihak Kepolisian akan memberikan kesempatan kepada LASDO terlebih dahulu untuk menyelesaiakan perkara pidana. Apabila LASDO merasa perlu melimpahkan perkara tersebut ke Kepolisian karna alasan dampak tindak pidana yang dilakukan berpotensi meluas dan dapat menimbulkan konflik horizontal di tengah masyarakat Donggo, maka perkara tersebut akan diserahkan ke Kepolisian setempat.
\end{abstract}

Kata Kunci: Lembaga Adat Donggo (Lasdo), Tindak Pidana, Ius Constituendum

\section{PENDAHULUAN}

Tatanan-tatanan hukum telah ada di Indonesia jauh sebelum masyarakat mengenal hukum modern. Masyarakat Indonesia telah hidup dengan aturan dan kebiasaan yang bersumber dari masyarakat ini selama beratusratus tahun yang lalu. Walaupun aturan-aturan hukum tidak berbentuk perundang-undangan yang kita kenal sekarang dengan segala ketentuan dan sanksi yang jelas dan tegas, tetapi tatanan hukum tersebut telah dapat memelihara keteraturan dan melindungi kepentingan masyarakat. Setiap kejahatan yang timbul dalam masyarakat dapat mengganggu keseimbangan tatanan masyarakat. Oleh karena itu, perlu diupayakan agar setiap kejahatan dapat diselesaikan agar keseimbangan tatanan masyarakat dapat dipulihkan. (Sudarto, 1997)
Setiap kelompok masyarakat yang menempati wilayah tertentu sebelum adanya ketentuan perundang-undangan sebagaimana yang dibuat oleh Negara, sudah mempunyai cara tersendiri untuk mengatur agar kehidupan individuindividu di dalam kelompok tersebut berjalan tertib dan teratur. Cara-cara tersebut muncul dari nilai-nilai pengalaman dan kebiasaankebiasaan yang sering dikenal dengan adat istiadat. Hukum adat berurat dan berakar pada kebudayaan tradisional yang hidup dari perwujudan perasaan hukum yang nyata dari masyarakat dan terus menerus dalam keadaan tumbuh dan berkembang seperti hidup itu sendiri.

Pada masyarakat kecamatan Donggo Kabupaten Bima Provinsi Nusa Tenggara Barat, sudah lama direkat oleh kentalnya hubungan kebersamaan (kasama weki) di dalam tataran 
budaya "berat sepikul ringan sejinjing" sebagai perwujudan nyata dari nilai-nilai adat, yang penyelesaian sengketanya masih mempercayakan kepada Lembaga adat atau lebih dikenal dengan Lembaga Adat Donggo (LASDO), dimana pada proses penyelesaian sengketa salah satunya tindak pidana terlebih dahulu harus melalui Lembaga Adat tersebut.

Meskipun dalam UUD 1945 Pasal 18B hasil amandemen mengakui adanya kesatuan masyarakat hukum adat beserta hal-hak tradisionalnya, namun fenomena adanya lembaga pidana adat LASDO tersebut apalagi untuk menyelesaikan tindak pidana belum ada payung hukumnya dalam sistem hukum pidana kita. Hal ini penting karena disamping untuk legalitasnya. juga yang mengatur seperti bagaimana beracara, serta prosedur-prosedur lain. Selain itu tidak ada yang menjamin apakah setelah dihukum berdasarkan hukum adat, apakah pelakunya akan dibebaskan dari jeratan hukum pidana nasional.

Sementara di satu sisi Undang-Undang Nomor 48 Tahun 2009 tentang Kekuasaan Kehakiman tidak ditemukan adanya lembaga adat yang berwenang untuk mengadili. UndangUndang tersebut hanya membagi pengadilan dalam empat lingkungan peradilan, yaitu Peradilan Umum, Peradilam Agama, Peradilan Militer, dan Peradilan Tata Usaha Negara.

Meskipun demikian, eksistensi lembaga adat Donggo yang dikenal dengan Lasdo ini tetap diakui baik oleh masyarakat setempat maupun oleh aparat penegak hukum disana, yang dalam hal ini adalah Kepolisian Sektor Donggo.

Penyelesaian tindak pidana yang terjadi di dalam masyarakat melalui lembaga adat merupakan salah satu bentuk penyelesian tindak pidana di luar sistem peradilan pidana formal. Walaupun saat ini telah dirumuskan dalam Rancangan KUHP (R-KUHP), Hal ini sejalan dengan pendapat Satjipto Rahardjo yang menyebut pertemuan dua bentuk hukum yang berbeda tersebut sangat dramatis, karena bukan hanya persoalan format hukum yang berbeda namun juga pertemuan antara dua cara hidup atau kultur. Di lain sisi, R-KUHP belum menjadi hukum positif yang dapat diterapkan dalam menyelesaikan tindak pidana. Oleh sebab itu secara yuridis pidana adat dan peradilan adat di Indonesia pun belum diakui secara tegas dan jelas oleh Undang-Undang.

Pada tataran implementasi, lembaga adat LASDO di kecamatan Donggo sangat berperan aktif dalam mengadili tindak pidana. Tokohtokoh adat setempat ditunjuk menjadi majelis dalam menentukan sanksi. Hilman Hadikusuma (2002 : 40) menyatakan biasanya yang bertindak sebagai hakim dalam lembaga adat adalah tokohtokoh adat (Kepala Lembaga adat) dan Ulama. Menurut Moh Koeno (2007 : 44), dalam hukum adat perkara diselesaikan berdasarkan tiga asas kerja untuk menghadapi perkara-perkara adat, yaitu asas rukun, patut dan keselarasan.

Keberadaan Peradilan adat LASDO memang dapat menjadi alternatif penyelesaian sengketa bagi masyarakat Donggo sebelum masuk ke sistem peradilan pidana nasional. Konsep ini dikenal sebagai restorative justice yang dicanangkan dalam R-KUHP. Namun disatu sisi perlu adanya kepastian hukum, misalnya terkait sejauhmana peran lembaga adat LASDO ini, jenis pidana apa saja yang menjadi kewenanganya mengadili, serta interaksi atau hubungannya dengan institusi resmi negara dalam menangani masalah pidana seperti kepolisian setempat. Hal yang tidak kalah pentingnya adalah bagaimana kekuatan hukum putusan lembaga adat tersebut serta legitimasi publik Donggo terhadapat putusan lembaga adat Lasdo.

\section{METODE PENELITIAN}

\section{Tahapan Penelitian}

Tahap Persiapan: a) Menentukan masalah yang akan dikaji dengan mencermati eksistensi Lembaga adat Donggo (Lasdo) dalam menyelesaikan tindak pidana di wilayah tersebut; b) Mendalami literatur untuk menentukan teori yang dianggap tepat dalam mengkaji permasalahan yang diangkat; c) Merancang proposal yang berisi permasalahan serta teori yang menjadi dasar sudut pandang hingga penganalisisan; Membuat instrumen pertanyaan untuk mencari serta menggali informasi sesuai rumusan masalah yang ditetapkan. 
Tahap Pelaksanaan: a) Melaksanakan penelitian pada objek kajian yang menekankan pencarian informasi pada tokoh masyarakat Donggo yang menjadi bagian dari Lembaga adat Lasdo; b) Mengumpulkan informasi ke dalam format pengumpulan data wawancara.

Tahap Akhir: a) Menelaah data sesuai landasan teori melalui uraian secara deskriptif; b) Membuat kesimpulan dan saran berdasarkan temuan penelitian.

\section{Lokasi Penelitian}

Penelitian ini akan dilaksanakan di Kecamatan Donggo Kabupaten Bima Nusa Tenggara Barat.

\section{Jenis Penelitian}

Jenis penelitian dalam penelitian ini adalah Penelitian Yuridis Empiris. Dikarenakan dalam penelitian ini meneliti orang dalam hubungan hidup di masyarakat. Zainuddin Ali (2009: 105) mengatakan bahwa penelitian Yuridis Empiris sebagai penelitian sosiologi hukum karena untuk melihat aspek-aspek hukum dalam interaksi sosial didalam masyarakat, dan berfungsi sebagai penunjang untuk mengidentifikasi dan mengklarifikasi temuan bahan non hukum bagi keperluan penelitian atau penulisan hukum.

\section{Metode dan Rancangan Penelitian}

Penelitian ini menggunakan metode kualitatif bersifat deskriptif bertujuan memberikan gambaran yang jelas, objektif, sistematis, dan cermat mengenai fakta-fakta yang diperoleh dari objek yang ditelaah.

\section{Sumber Data/Bahan Hukum}

Data Primer diperoleh melalui wawancara dengan tokoh adat Donggo dan tokoh masyarakat Donggo yang dalam hal ini juga mencakup aparat kepolisian setempat.

Data Sekunder, seperti dokumen-dokumen resmi, buku-buku yang berhubungan dengan objek penelitian, hasil penelitian dalam bentuk laporan, dan peraturan perundang-undangan, data ini dapat dibagi menjadi: a) Bahan Hukum Primer; b) Bahan Hukum Sekunder; c) Bahan Hukum Tersier

\section{Teknik Pengumpulan Data/Bahan Hukum}

Pengumpulan data dalam penelitian ini dilakukan melalui tahap-tahap sebagai berikut: a) Studi Kepustakaan (library research). Diperoleh melalui penelitian kepustakaan yang bersumber dari Peraturan Perundang-undangan, buku-buku, dokumen resmi, publikasi, dan hasil penelitian, khususnya yang terkait hukum pidana adat; b) Studi Lapangan (field researcch). Diperlukan sebagai data penunjang, diperoleh dari para pihak yang telah ditentukan sebagai informan atau narasumber, yaitu Ketua Lembaga Adat Donggo (LASDO) serta Pihak-pihak terkait yang mengetahui bagaimakah pelakasanaan dan aplikasi dari Hukum Adat dan Peranan Lembaga adat di Kecamatan Donggo.

\section{Analisis Bahan Hukum}

Berdasarkan sifat penelitian ini yang menggunakan metode penelitian bersifat analitis teori, analisa data yang dipergunakan adalah pendekatan kualitatif terhadap data primer dan data sekunder. Analisa tersebut meliputi isi dan struktur hukum positif, yaitu suatu kegiatan yang dilakukan oleh penulis untuk menentukan isi atau makna hukum yang dijadikan rujukan dalam menyelesaikan permasalahan hukum yang menjadi objek kajian, serta menggunakan teori interprestasi, yaitu teori yang menyatakan kesesuain antara bahan hukum dengan doktrindoktrin dengan penelitian lapangan yaitu peran lembaga adat Donggo (Lasdo) dalam menangani perkara pidana serta teori argumentasi yang lebih banyak membahas tentang doktrin-doktrin dan bahan hukum yang sudah ada. Simpulan dalam penelitian ini yakni dengan menggunakan metode berfikir secara induktif.

\section{HASIL PENELITIAN}

\section{Gambaran Umum Lokasi Penelitian}

Kecamatan Donggo merupakan salah satu dari delapan belas kecamatan yang ada di Kabupaten Bima Nusa Tenggara Barat. Terdapat beberapa desa di Kecamatan Donggo, yaitu O'o, Bumi Pajo, Mpili, Ndano Na'E, Rora, Mbawa, Doridungga, Kala, dan Palama. Kecamatan Donggo beribukota di desa O'o. Kecamatan Donggo merupakan kecamatan yang terletak di dataran tinggi dengan ketinggian $714 \mathrm{Mdpl}$ yang merupakan tertinggi di Kabupaten Bima, dimana kecamatan ini berbatasan langsung dengan Kecamatan Soromandi, Kecamatan Bolo, Kecamatan Madapangga, dan Kabupaten 
Dompu. Luas wilayah kecamatan Donggo adalah 123, $83 \mathrm{Km}^{2}$. Jumlah penduduk kecamatan Donggo berdasarkan data Badan Pusat Statistik Kabupaten Bima per tahun 2014 adalah sebanyak 18.584 jiwa dengan mayoritas penduduk beragama Islam sebanyak 17.432 jiwa, Katolik sebanyak 964 jiwa dan Protestan sebanyak 188 jiwa. Mayoritas penduduk Donggo bermata pencaharian sebagai petani. (BPS Kabupaten Bima).

\section{Selintas Tentang Lembaga Adat Donggo (LASDO)}

Lembaga Adat Donggo (LASDO) lahir sekitar tahun $1908 \mathrm{M}$. Hal ini dilatar belakangi oleh adat yang berlaku di Donggo dimana sangat diwarnai oleh hukum Islam. Ditambah lagi dengan faktor ketidaksukaan Ncuhi Kala (pimpinan masyarakat Donggo, sejak zaman kerajaan Mbojo-Bima) atas pemberlakuan hukum kolonial Belanda yang diberlakukan di Indonesia, khususnya di Donggo. LASDO sebenarnya adalah singkatan dari Lembaga Adat dan Syari'at Donggo, namun masyarakat awam sekarang lebih mengenalnya dengan istilah Lembaga adat saja. Padahal kata Syari'at itu penting dimasukan, mengingat hukum yang digunakan oleh LASDO salah satunya bersumber dari ajaran Islam, agama mayoritas masyarakat Donggo.

Struktur Lembaga adat Donggo (LASDO) dipimpin oleh ketua adat yang diberi gelar OMPU TUA. Kemudian dibawah ketua, yang bertugas sebagai sekretaris diberi gelar OMPU SAMPELA. Ompu Sampela bertugas sebagai administrasi dan mendata permasalahan hukum masyarakat. Untuk pendanaan dan kas ditunjuk seorang BENDAHARA. Kemudian ada satuan khusus yang diberi gelar NCUHI dan NCAWU. Ncuhi dan Ncawu ini bertugas menyerap aspirasi masyarakat Donggo yang dilaporkan ke anggota adat, untuk disampaikan kepada Ketua Adat. Menyerap aspirasi ini termasuk menerima laporan terkait permasalahan hukum. Untuk hukum pidana, diterima oleh Ncawu sedangkan untuk permasalahan hukum lain seperti perdata, perkawinan, waris dan sebagainya ditangani oleh Ncuhi. Struktur Lembaga adat Donggo ini memiliki garis koordinasi dengan DEWAN
SYURO. Dewan Syuro bertugas memberikan masukan kepada OMPU TUA terkait segala hal yang berkaitan dengan masyarakat adat Donggo. Dewan Syuro berisi para sesepuh Donggo dari beberapa tokoh, seperti tokoh agama dan tokoh pendidikan.

Tidak semua masyarakat Donggo berhak masuk dalam kepengurusan Lembaga Adat dan Syari'at Donggo (LASDO), ada beberapa kriteria khusus yang harus terpenuhi. Hal ini sebagaimana dikatakan oleh Ketua LASDO: "Yang berhak duduk dalam struktur Lembaga adat Donggo adalah penduduk asli Donggo yang dibuktikan dengan silsilah keluarga dan akta kelahiran. Selain itu, yang memiliki garis keturunan Ncuhi Kala dan berdomisili di Donggo. Faktor usia juga tidak bisa dikesampingkan. Minimal usia yang ingin menjadi bagian dari anggota LASDO adalah 40 (empat puluh tahun). Mengingat di usia itu manusia sudah masuk ke tahap kematangan berpikir dan penuh kebijaksanaa dalam bertindak."

Setelah memenuhi kriteria di atas, mekanisme selanjutnya adalah terkait masalah rekruitmen anggota Lembaga adat. Menurut Ketua Lembaga Adat dan Syari'at Donggo, rekruitmen pengurus Lembaga adat Donggo dilakukan secara musyawarah mufakat oleh tokoh-tokoh sesepuh adat dengan Ompu Tua. Hal ini penting karena para tokoh sesepuh paham mengenai asal-usul dan silsilah para anggota yang akan direkrut.

Pergantian kepengurusan Lembaga adat Donggo tidak dibatasi periodesasi sebagaimana masa jabatan Kepala Desa, Bupati, Gubernur, Presiden dan jabatan politik lainnya. Misalnya masa kepemimpinan presiden dibatasi dalam kurun waktu lima tahun sekali, begitupun Bupati dan Gubernur. Lembaga adat dan syari'at Donggo lebih berpatokan pada sistem pemerintahan kerajaan/kesultanan dalam Islam. Masa jabatan Ketua Adat ditentukan hingga Ompu tua tutup usia atau meninggal dunia, atau ada alasan lain yang membuat Ompu tua tidak mampu menjalankan tugasnya sebagai Ketua adat LASDO. Hal ini juga berlaku pada struktur keanggotaan lain, seperti Ompu Sampela, 
Ncuhi, Ncawu, dan anggota lain. Hal ini sebagaimana dikemukakan oleh Ketua LASDO, yaitu sebagai berikut: "Berakhirnya status kepengurusan Lembaga Adat Donggo adalah ketika yang bersangkutan meninggal dunia, atau ada alasan lain yang bersifat pribadi seperti masalah kesehatan, tidak mampu lagi menjalankan tugas, atau pindah domisili ke luar Donggo"

Berdasar keterangan terkait masa jabatan di atas, disatu sisi perlu diapresiasi karena masih mempertahankan kearifan lokal masyarakat Donggo, namun disisi lain menurut penulis hal ini akan membahayakan soliditas masyarakat mengingat ketiadaan kaderisasi dari pengurus LASDO. Apalagi jika kita lihat fenomena demokrasi yang dianut oleh bangsa Indonesia. Bukan tidak mungkin kepercayaan masyarakat Donggo akan terdegradasi jika lembaga adat ini menjalankan kepengurusan yang tidak adil menurut mereka (masyarakat Donggo) sehingga akan bermuara pada terancamnya eksistensi lembaga LASDO ini.

Peran Lembaga Adat Donggo (LASDO) Dalam Menyelesaikan Tindak Pidana Di Kecamatan Donggo Kabupaten Bima

Sebagai lembaga adat, yang lahir jauh sebelum Indonesia merdeka pada tahun 1945 eksistensi Lembaga adat dan Syari'at Donggo (LASDO) sangat melekat dengan masyarakat Donggo. Eksistensi itu terkristalisasi dari keterlibatan lembaga adat ini dalam segala aspek kehidupan masyarakat setempat, baik itu masalah yang berkaitan dengan hubungan sosial kemasyarakatan, hingga berkaitan dengan hubungan dengan ketuhanan dan lingkungan alam. Salah satu keterlibatan LASDO dalam sosial kemasyarakatan adalah terkait persoalan hukum, seperti masalah hukum pidana.

Eksistensi lembaga adat Donggo ini sebagaimana yang dikemukakan oleh Kapolsek Donggo, yaitu sebagai berikut: "Lembaga adat diakui oleh UU keberadaannya. Oleh karena itu, tidak ada alasan bagi kita untuk menolak kehadirannya, karena negara kita adalah negara hukum. Kepolisian Donggo sangat berterima kasih kepada LASDO karena mampu meringankan beban kepolisian. Saya harap terus berkolaborasi. Karena jujur saja, masyarakat disini lebih segan dan lebih menghormati lembaga adat. Sehingga keputusannya sangat dihargai dan diikuti”

Hal senada juga dikemukakan oleh tokoh masyarakat sekaligus tokoh pendidikan, bernama Makarau yang menyatakan bahwa LASDO terlibat semua dalam permasalahan yang ada di Donggo. Tidak hanya di Donggo timur, melainkan Donggo barat juga.

Permasalahan yang terkait pidana adalah permasalahan yang bersifat publik. Artinya dia bersentuhan langsung dengan masyarakat dan sangat berpotensi menimbulkan benturan dan konflik ditengah masyarakat apabila masalah pidana ini dirasa merugikan pihak-pihak terkait, misalnya kebuntuan dalam akses menuju keadilan masyarakat ditemui. Oleh karena itu, kehadiran lembaga adat LASDO sangat strategis dalam penyelesaian perkara pidana, baik sebelum Indonesia merdeka maupun setelah Indonesia merdeka seperti sekarang ini. Banyak perkara pidana yang terjadi di lingkup masyarakat Donggo yang ditangani dan diselesaikan oleh lembaga adat LASDO. Namun, kelemahan dari segi administrasi khususnya terkait pendataan jumlah kasus pidana sejak LASDO terbentuk dirasa kurang mampu mendukung hal tersebut.

Segala permasalahan hukum yang terjadi dilingkup kecamatan Donggo, mulai dari masalah perdata, pidana, perkawinan hingga harta warisan hingga sengketa lahan tidak terlepas dari peranan lembaga adat LASDO dalam penyelesaiannya. Peranan tersebut terkristalisasi dari berbagai cara, namun umumnya dilakukan dengan cara mediasi. Lembaga adat LASDO lebih banyak menjadi fasilitator sekaligus decisition maker, dan apa yang menjadi putusannya akan diterima dengan tangan terbuka oleh pihak-pihak yang bersengketa.

Untuk perkara pidana, di kecamatan Donggo LASDO memiliki peran strategis dalam penyelesaian tindak pidana. Tindak pidana yang bisa ditangani oleh lembaga adat ini mulai dari kategori ringan hingga kategori berat. Hal ini sebagaimana yang dikemukakan oleh ketua 
lembaga adat LASDO: "Jenis tindak pidana yang dapat ditangani LASDO adalah mulai yang bersifat ringan, hingga berat. Seperti pencurian, pemerasan hingga pembunuhan. Selama tindak pidana itu berpotensi menimbulkan konflik sosial ditengah masyarakat, maka LASDO tetap terlibat dalam penyelesaiannya"

Sebagaimana yang disampaikan oleh Ketua adat LASDO di atas, peran lembaga adat dalam penyelesaian tindak pidana di kecamatan Donggo adalah lebih kepada menjadi fasilitator dan mediasi antar pihak pelaku dan korban atau keluarga korban. Dalam upaya mediasi dan fasilitator ini Lembaga adat akan berkoordinasi dengan aparat penegak hukum dalam hal ini kepolisian Resort Donggo. Pihak LASDO akan memanggil pihak-pihak terkait dalam permasalahan pidana ini, dengan cara mendengarkan posisi kasus baik dari pihak korban maupun dari pihak pelaku. Pemanggilan ini akan dilakukan diwaktu yang berbeda antara dua pihak terkait.

Setelah mendengar posisi kasus dari kedua belah pihak dalam waktu yang berbeda tersebut, maka langkah selanjutnya dari lembaga adat LASDO adalah dengan melakukan konfrontasi antara pihak korban dan pelaku dalam satu waktu dimana tempatnya adalah di kediaman Ketua Adat LASDO. Hal ini dilakukan agar ditemukan kebenaran materiil sesuai dengan keterangan pihak terkait.

Peran lembaga adat LASDO ini sesuai dengan apa yang disampaikan oleh Ketua Adat, yaitu sebagai berikut: "Peran Lembaga adat dalam menyelesaikan tindak pidana adalah dengan melakukan investigasi serta menelaah posisi kasus serta semua yang terlibat. Misalnya korban, pelaku, serta saksi-saksi jika ada. Namun jika tidak ada saksi yang melihat, cukup dengan saksi korban. Baru kemudian dikonfrontasikan dengan pelaku. Setelah itu, perkara tersebut akan dibicarakan sanksi dan solusinya dalam sidang atau rapat lembaga adat yang dipimpin oleh Ketua LASDO. Biasanya sidang tersebut dilakukan di rumah Ketua adat yang dihadiri oleh Ompu Tua, Ompu Sampela dan Dewan Syuro dan kepala desa asal korban dan pelaku"
Dalam pengambilan keputusan terkait masalah pidana, lembaga adat LASDO dalam hal ini Ompu Tua, Ompu Sampela dan Dewan Syuro akan melakukan sidang tertutup yang dilaksanakan di kediaman Ompu Tua. Kediaman Ompu Tua merupakan tempat menyelesaiakan segala persoalan yang bersentuhan dengan lembaga adat LASDO. Hal ini dilakukan secara turun-temurun sejak nenek moyang dulu.

Menurut Ketua Adat LASDO, penyelesaian perkara pidana oleh lembaga Adat ini menggunakan sumber hukum yang berasal dari hukum Islam dan kepercayaan nenek moyang dulu. Adapun mekanisme pengambilan keputusan oleh Lembaga Adat LASDO adalah jika posisi kasus telah ditelaah maka Lembaga adat dibawah Ketua Adat melakukan musyawarah untuk mencapai mufakat dengan jajarannya yaitu Ompu Sampela dan Dewan Syuro. Jika tidak tercapai sebuah keputusan dalam musyawarah, maka diserahkan kepada Ompu Tua (Ketua adat) dalam menentukannya. Hal ini sesuai dengan keterangan Ketua Adat LASDO, yaitu sebagai berikut: "Mekanisme pengambilan keputusan adalah, setelah menelaah posisi kasus maka Lembaga adat dibawah Ketua Adat melakukan musyawarah untuk mencapai mufakat dengan jajarannya yaitu Ompu Sampela dan dewan Syuro. Jika tidak tercapai sebuah keputusan dalam musyawarah, maka diserahkan kepada Ketua adat dalam menentukannya".

Dalam hal perumusan sanksi pidananya, pihak lembaga adat LASDO akan mengkategorikannya sesuai dengan beratringannya tindak pidana yang dilakukan oleh pelaku terhadap korban. Ada dua jenis sanksi pidana yang dikenakan oleh Lembaga Adat LASDO kepada pelaku tindak pidana. Pertama sanksinya adalah sesuai dengan apa yang dilakukan pelaku terhadap korban, dan kedua pidana pengganti sesuai dengan kehendak pihak korban atau keluarga korban. Pidana kedua ini dilaksanakan jika pihak korban atau keluarga korban bersedia memberi ma'af kepada pelaku. Umumnya jika perbuatan pidana itu berkategori berat, seperti pembunuhan. Hal ini sebagaimana 
yang dikemukakan oleh Ketua Adat LASDO, yakni sebagai berikut: "Jenis sanksi adalah sesuai dengan yang dilakukan oleh pelaku terhadap korban. Misalnya kalau berat seperti pembunuhan, maka pelaku akan dibunuh kembali kecuali ada pemaafan dari keluarga korban. Jika keluarga korban memberikan maaf, maka pelaku akan diwajibkan menanggung biaya hidup anak atau istri atau suami korban. Jika tindak pidana dikategorikan ringan, seperti pemukulan, penganiayaan maka jenis sanksinya adalah sesuai dengan perbuatan tersebut oleh korban atau pihak keluarga korban”.

Terkait penjatuhan sanksi pidana oleh Lembaga adat LASDO, salah satu tokoh masyarakat bernama Makarau memiliki pendapat yang sedikit berbeda, khususnya terkait masalah efek jera. Beliau menyatakan: "Masayarakat Donggo pada umumnya menaati hukum pidana yang dikenakan oleh lembaga adat LASDO. Tetapi menurut saya, itu tidak terlalu membuat efek jera di lingkup masyarakat. Polisi saya rasa lebih bagus turun tangan, sematamata agar masyarakat yang melakukan pidana menjadi jera dan tidak mngulangi lagi perbuatannya.

Apa yang dikatakan oleh tokoh masyarakat di atas, bisa dibenarkan. Mengingat Lembaga adat LASDO tidak memiliki instrumen hukum yang kuat untuk memaksakan penjatuhan sanksi pidana kepada pelaku tindak pidana.

Setelah dijatuhkan sanksi kepada pelaku tindak pidana, masalah selanjutnya adalah terkait dengan eksekusi sanksi pidana. Menurut Ketua Adat LASDO, eksekusi sanksi pidana dilakukan oleh korban terhadap pelaku. Namun bisa juga diserahkan kepada keluarga korban atau anggota Lembaga adat. Eksekusinya dilakukan di rumah ketua adat atau di kantor desa asal korban yang disaksikan oleh masyarakat setempat. Lebih lanjut menurut beliau, hal ini lembaga Adat LASDO menerapkan sesuai dengan hukum Islam, dimana eksekusi sanksi pidana disaksikan oleh masyarakat umum. Hal ini dilakukan untuk mencegah orang lain untuk mengikuti perbuatan pidana yang dilakukan oleh pelaku.
Menurut ketua adat LASDO, selama ini belum pernah dijumpai masalah sengketa penjatuhan sanksi pidana kepada pelaku, baik dari korban dan keluarganya maupun dari pelaku. Semuanya menerima sanksi yang dijatuhkan secara sukarela. Kalaupun dikemudian hari terdapat sengketa penjatuhan sanksi pidana, maka Lembaga Adat LASDO memiliki kewenangan untuk memaksa agar sanksi tersebut diterima. Hal ini sebagaimana yang disampaikan oleh beliau, yaitu sebagai berikut: "Sebenarnya sengketa pidana adat dalam masyarakat Donggo belum pernah dijumpai. Masyarakat terkait biasanya akan langsung menerima sanksi yang dijatuhkan. Oleh karena itu tidak kita jumpai sengketa. Kalaupun di kemudian hari ada sengketa, Lembaga adat punya kekuasaan memaksa agar masyarakat menerima sanksi yang dijatuhkan”

Berdasarkan keterangan di atas, tidak ditemukan perselisihan terkait dengan penjatuhan sanksi pidana oleh lembaga adat. Namun disayangkan tidak dijelaskan lebih lanjut mengenai mekanisme jika terjadi perselisihan terhadap sengketa adat. Ketua adat LASDO hanya memberikan garis besar mengenai upaya pemaksaan yang dilakukan LASDO jika dikemudian hari terjadi perselisihan tersebut.

\section{Tindak Pidana Yang Menjadi Kewenangan Penyelesaian Lembaga Adat Donggo}

Sebagaimana diketahui bahwa terdapat beberapa kategori tindak pidana, yaitu tindak pidana berkategori ringan (Tipiring), maupun tindak pidana yang berkategori berat. Adapun satu contoh tindak pidana ringan adalah pelanggaran lalu lintas, sedangkan tindak pidana berat seperti penganiayaan, pembunuhan, makar dan sebagainya.

Di Kecamatan Donggo, lembaga adat Donggo LASDO juga memiliki peran strategis dalam penyelesaian tindak pidana, baik itu yang bersifat ringan maupun bersifat berat. Hal ini sebagaimana diungkapkan oleh ketua Adat LASDO yaitu sebagai berikut: "Jenis tindak pidana yang dapat ditangani LASDO adalah mulai yang bersifat ringan, hingga berat. Seperti pencurian, pemerasan hingga pembunuhan. Selama tindak pidana itu berpotensi 
menimbulkan konflik sosial ditengah masyarakat, maka LASDO tetap terlibat dalam penyelesaiannya”.

Dari keterangan di atas terlihat keterlibatan LASDO dalam penyelesaian tindak pidana, baik yang bersifat ringan maupun yang berat. LASDO akan terlibat dalam penanganan tindak pidana jika ada penilaian dari pihak LASDO terkait potensi konflik sosial ditengah masyarakat yang diakibatkan oleh tindak pidana tersebut. Artinya, meskipun tindak pidana itu bersifat ringan tetapi jika berpotensi menimbulkan chaos, maka LASDO akan terlibat dalam penanganannya. Bukan berarti tindak pidana ringan jauh dari potensi konflik ditengah masyarakat. Sebaliknya, belum tentu tindak pidana berat dapat berpotensi menimbulkan konflik sosial sehingga LASDO harus turun tangan dalam penyelesaiannya.

Menurut Ketua Adat LASDO, penanganan tindak pidana berat teraktual yang melibatkan LASDO adalah pada kasus pengeroyokan yang menyebabkan pembunuhan yang dilakukan beberapa pemuda desa Doridungga terhadap korban bernama Dewa Bakti Negara yang beralamat di dusun 2 desa O'o Kecamatan Donggo pada tahun 2017 lalu. (http://www.metromini.co.id/2017/06/dewatewas-ditikam-di-desa-kemunti-desa.html)

Dalam kasus tersebut LASDO berperan sebagai mediator antara keluarga korban dan para pelaku. Setelah mediasi dilakukan, maka potensi kerusuhan yang semula besar terjadi bisa diminimalisir. Meskipun demikian proses hukum kemudian dilimpahkan kepada kepolisian setempat.

Meskipun LASDO diberi kewenangan untuk terlibat dalam penyelesaian tindak pidana, namun menurut salah satu tokoh masyarakat bernama Makarau, penanganan tindak pidana khususnya yang bersifat berat sebaiknya ditangani oleh pihak kepolisian setempat. Hal ini berkaitan dengan efek jera yang ditimbulkan serta semakin tergerusnya generasi sekarang menghargai adat-istiadat masyarakat Donggo sebagai efek dari globalisasi. Menurutnya sanksi yang diberikan oleh lembaga Adat LASDO dirasa kurang efektif dalam mencegah dan menanggulangi tindak pidana berat dikemudian hari. Berikut pernyataan tokoh masyarakat tersebut: "Menurut saya, tidak begitu efektif terutama dalam hal menimbulkan efek jera. Karena masyarakat sekarang kurang begitu menghargai adat-istiadat yang berlaku di masyarakat Donggo karena pengaruh perkembangan zaman. Apalagi jika dihadapkan pada anak-anak remaja sekarang. Hukum pidana Indonesia seperti penjara dan denda saya rasa lebih cocok dan itu bisa menimbulkan efek jera"

Lebih lanjut Beliau mengatakan bahwa penyelesaian tindak pidana sebaiknya diserahkan kepada pihak yang berwajib dalam hal ini adalah Kepolisian Resort Donggo. LASDO cukup diberi tugas sebagai fasilitator dalam mempertemukan pihak korban (victim) dan (offender). Berikut apa yang disampaikan oleh beliau: "Untuk penyelesaian tindak pidana menurut saya lebih baik diserahkan saja ke kepolisian. Biarlah lembaga adat hanya menjadi penghubung antara pelaku dan korban, selebihnya kita serahkan ke kepolisian karena mereka diberi tugas untuk itu oleh negara"

Berangkat dari pendapat di atas, penulis lebih sepakat dengan apa yang dikemukakan oleh tokoh masyarakat. Hal ini dikarenakan selain Kepolisian diberi kewenangan oleh UU, mereka juga dilengkapi dengan SDM yang profesional dan terlatih untuk penanganan tindak pidana. Disamping itu, instrumen hukum yang digunakan jelas, bersifat memaksa dan mengikat bagi siapapun pelanggar hukum. Dengan demikian, apa yang menjadi tujuan hukum itu bisa dengan mudah tercapai yaitu terciptanya general prevention dan special prevention, yaitu perlindungan bagi masyarakat agar tidak mengikuti tindak pidana yang dilakukan pelaku dan perlindungan dari pelaku tindak pidana agar jangan sampai mengulangi tindak pidana yang pernah dilakukan.

Sinergisitas Lembaga Adat Donggo (LASDO) Dan Aparat Kepolisian Sektor Donggo Dalam Penanganan Tindak Pidana

Penanganan perkara pidana sebagaimana diatur dalam KUHAP melibatkan beberapa institusi penegak hukum, diantaranya Kepolisian. Dalam konteks perkara pidana yang 
dilakukan di masyarakat Donggo, lembaga adat dan syari'at Donggo (LASDO) memiliki peran strategis dalam penanganannya. Hal ini dikarenakan LASDO masih diakui eksistensinya, baik oleh masyarakat Donggo, institusi penegak hukum maupun pemerintahan setempat. Dengan kata lain, polisi sebagai aparat penegak hukum sebagaimana amanat KUHAP yang merupakan kodifikasi hukum Nasional memang memiliki kewenangan yang diberikan oleh Undang-Undang untuk menangani perkara pidana dalam hal penyelidikan dan penyidikan. Namun disisi lain tidak bisa mengesampingkan Lembaga adat LASDO. Eksistensi lembaga adat Donggo ini sebagaimana yang dikemukakan oleh Kapolsek Donggo yaitu sebagai berikut: "Sebenarnya saya baru bertugas di Donggo. Tapi menurut keterangan anggota yang telah lama bertugas, memang disini LASDO sangat diakui keberadaannya. Termasuk dalam hal menangani masalah pidana yang dilakukan di Donggo".

Hal senada juga diungkapkan oleh salah satu tokoh masyarakat sekaligus tokoh pendidikan bernama Makarau yang menyatakan bahwa eksistensi LASDO khususnya dalam penanganan perkara pidana masih diakui.

Berangkat dari adanya lembaga adat LASDO disatu sisi dan keberadaan Kepolisian disisi lain, perlu adanya kolaborasi dan sinergisitas antara dua lembaga tersebut khususnya dalam penanganan perkara pidana. Ketua Lembaga adat LASDO menyatakan bahwa: "Sinergisitas antara LASDO dan kepolisian biasanya dilakukan jika menyentuh keamanan pelaku tindak pidana. Biar bagaimanapun, pelaku juga perlu mendapat perlindungan. Namun, apabila korban atau keluarga korban dan pelaku sudah menerima sanksi yang diberikan oleh LASDO, maka perkaranya tidak akan dilanjutkan ke kepolisian. LASDO dengan pertimbangan tersebut akan memberikan rekomendasi kepada kepolisian untuk tidak melanjutkan kasus ke tahap berikutnya"

Meskipun tidak ada Standart Operating Procedure (SOP) yang tertulis mengenai pembagian ranah penanganan perkara pidana oleh LASDO dan Kepolisian Resort Donggo, namun antara kedua lembaga ini saling menghormati dan menghargai satu sama lain. Hal ini sebagaimana menurut Ketua adat LASDO, yaitu sebagai berikut: "Tidak ada SOP yang tertulis. Hanya mengandalkan komunikasi dan musyawarah yang intens antara LASDO dan kepolisian. Dan Alhamdulillah, selama ini berjalan lancar. Karena antara LASDO dan kepolisian saling menghargai keberadaan dan fungsi satu sama lain"

Hal yang senada juga dikemukakan oleh Kapolsek Donggo. Beliau menyatakan: "Sebetulnya tidak ada dasar hukum tertulis antara LASDO dan Polsek Donggo dalam pembagian penanganan kasusnya. Kedua lembaga ini saling mengisi satu dengan yang lain. Polsek Donggo menghormati lembaga adat dan begitupun lembaga adat Donggo menghormati Kepolisian Resort Donggo. Itulah modal dasar kami dalam berinteraksi. Artinya disini berlaku hukum yang tidak tertulis, yang notabene berlaku dalam masyarakat adat".

Sinergisitas dan kolaborasi antara Lembaga Adat LASDO dan Kepolisian Resort Donggo sebenarnya sering diimplementasikan dalam kasus-kasus tertentu khususnya kasus pidana. Teraktual adalah sinergisitas penanganan kasus yang terjadi pada tahun 2017 lalu. Kasus tersebut bermula dari pengeroyokan yang menyebabkan meninggalnya korban atas nama Dewa Bakti Negara warga dusun 2 Desa O'o Kecamatan Donggo. Pada kasus tersebut pelaku sangat sulit ditemukan oleh pihak kepolisian karena dianggap melarikan diri atau terkesan disembunyikan oleh keluarga pelaku. Hal tersebut menyebabkan kemarah luar biasa dari pihak korban serta masyarakat O'o pada umumnya sehingga berpotensi menimbulkan konflik ditengah masyarakat. LASDO berbekal kedekatan emosional dengan masyarakat Donggo melakukan pendekatan khusus kepada pihak keluarga pelaku. Setelah melalui negosiasi yang panjang, akhirnya pelaku menyerahkan diri ke pihak LASDO dan Kepolisian setempat.

Pelaku yang berjumlah beberapa orang tersebut kemudian diamankan di kediaman ketua adat Donggo, sebelum diserahkan kepada pihak kepolisian dan babinsa setempat. Hal ini dilakukan atas pertimbangan menghindari 
konflik dan main hakim sendiri oleh masyarakat setempat terhadap pelaku. Hal ini sebagaimana dikemukakan oleh Kapolsek Donggo yaitu sebagai berikut: "Antara LASDO dan Kepolisian sektor Donggo pada prinsipnya saling menghormati satu sama lain. Kedua lembaga saling berkolaborasi. Terkadang pendekatan oleh LASDO kepada pelaku tindak pidana lebih diterima oleh masyarakat setempat, jika pelaku mencoba melarikan diri. Polisi memanfaatkan hal itu untuk bisa melakukan penyelidikan terhadap suatu kasus. Mungkin masyarakat takut ditangani kepolisian, padahal hal tersebut bukan menjadi alasan yang dibenarkan. Karena tugas polisi itu adalah melindungi dan mengayomi masyarakat. Kolaborasi terakhir dari kami dan LASDO dalam perkara pidana adalah ketika kasus pembunuhan pemuda desa O'o atas nama Dewa Bakti. LASDO dengan perannya seperti mediasi dengan pihak keluarga pelaku agar tidak melarikan diri. Seperti yang saya katakan tadi, bahwa terkadang pendekatan LASDO terhadap pelaku atau korban di Donggo ini lebih diterima oleh warga dibanding kita di kepolisian. Untuk menghindari amukan massa, maka pelaku kemudian diserahkan oleh pihak LASDO ke kami selaku kepolisian untuk diproses sebagaimana mestinya"

Sinergisitas antara Lembaga Adat Donggo dan Kepolisian dalam penanganan tindak pidana di Donggo terjalin sangat harmonis, meskipun tidak ada aturan tertulis mengenai hal itu. Tidak ada perselisihan atau sengketa dalam pembagian penanganan kasus pidana, tentunya dengan beberapa pertimbangan seperti eskalasi potensi konflik yang berpotensi terjadi dari tindak pidana yang telah dilakukan. Pernyataan ini diperkuat oleh Kapolsek Donggo, sebagaimana di bawah ini: "Sejauh saya menjadi Kapolsek disini belum dijumpai sengketa kewenangan. Jika terjadi tindak pidana seperti pemukulan dan penganiayaan akibat kenakalan remaja, biasanya itu cukup dibina oleh LASDO dan Babinsa setempat. Namun, upaya akan diamankan di polsek Donggo apabila ada kekhawatiran terjadinya aksi masa atau balas dendam dari pihak korban atau pelaku”
Lebih lanjut Kapolsek Donggo mengatakan bahwa: "Disini prinsip saling menghormati dan menghargai sangat kental. Jika dirasa Polisi perlu turun tangan dalam melakukan penyelidikan dan penyidikan kasus, serta di P21 maka itu dilakukan. Tentunya harus mendengarkan pemaparan dan pertimbangan LASDO. Namun jika tidak, maka cukup diselesaikan oleh LASDO saja”.

Kehadiran Lembaga Adat LASDO dalam membantu kepolisian dalam penanganan perkara khususnya pidana sangat positif. Artinya disatu sisi penegakan hukum sesuai hukum positif Indonesia tetap berjalan, disisi lain tidak melupakan Lembaga adat yang merupakan kristalisasi kearifan lokal (local wisdom) yang harus tetap dijaga eksistensinya. Apalagi ditengah upaya pembentukan Undang-Undang yang baru dalam ranah R-KUHP dan R-KUHAP sebagai Ius Constituendum. Kita tidak melupakan dari mana asal kita, tetap dimunculkan keIndonesiaan-an ditengah gempuran globalisasi, termasuk dalam dunia hukum kita.

Sinergisitas dan kolaborasi semacam ini layak dijaga dan dipertahankan, mengingat hukum adat merupakan hukum yang tetap hidup di masyarakat (living law). Ketua Lembaga adat LASDO, Kapolsek Donggo dan tokoh masyarakat Donggo masing-masing sepakat akan hal ini. Kapolsek Donggo berpendapat, sebagaimana hasil wawancara dengan peneliti, yaitu sebagai berikut: "Perlu harus dijaga dan dilestarikan. Masyarakat Donggo adalah masyarakat yang sangat menghormati adatistiadatnya, juga lembaga adatnya. Disinilah simbiosis mutualisme terwujud antara LASDO dan Polsek Donggo. Meskipun kelak KUHP dan KUHAP diperbaharui, agar pemerintah tidak melupakan eksistensi hukum adat atau hukum pidana adat dalam pasal-pasalnya. Karena jujur, kami disini sangat terbantu dengan keberadaan LASDO"

Hal senada juga disampaikan oleh Ketua Adat Donggo, yakni sebagai berikut: "Kami sebagai masyarakat adat, khususnya Donggo sangat berharap kepada pemerintah Republik Indonesia untuk tetap mengakui keberadaan kami serta memberikan ruang yang seluas- 
luasnya agar hukum adat kami bisa tetap berlaku di masyarakat Indonesia pada umumnya dan masyarakat Donggo khususnya”.

\section{DAFTAR PUSTAKA}

Undang-Undang Dasar 1945 (Amandemen)

Undang-Undang Nomor 48 Tahun 2009

Tentang Kekuasaan Kehakiman

Peraturan Menteri Dalam Negeri Nomor 5 Tahun 2007

Peraturan Daerah Sumbawa Nomor 23 Tahun 2007

Amir Ilyas, 2012. Asas-Asas Hukum Pidana; memahami tindak pidana dan pertanggungjawaban pidana sebagai syarat pemidanaan. Yogyakarta : Rangkang Offset.

Bambang Waluyo. 2002. Penelitian Hukum dalam Praktik. Jakarta : Sinar Grafika.

Barda Nawawi Arief. 2010. Bunga Rampai Kebijakan Hukum Pidana; Perkembangan Konsep Penyusunan KUHP Baru, edisi 1, ctk-2, Jakarta: Kencana.

Hilman Hadikusuma. 2002. Pengantar Hukum Adat Indonesia. Bandung: Mandar Maju.

I Made Widnyana. 1993. Kapita Selekta Hukum Pidana Adat, Bandung: PT Eresco.

Mohammad Ekaputra. 2010. Dasar-dasar Hukum Pidana edisi 2. Medan: USU Press.

Moh Koesno. 1974. Catatan Terhadap Hukum Adat Dewasa ini. Surabaya: Erlangga University Press.

P.A.F. Laminanting. 1996. Dasar-dasar Hukum Pidana Indonesia. Bandung: PT. Citra Aditya Bhakti.

Rancangan KUHP Nasional edisi tahun 2008.

Saragih. 1994. Pengantar Hukum Adat Indonesia. Bandung : Transito.

Sudarto. 1997. Hukum dan Hukuman Pidana. Bandung: Alumni.

Ter Haar Bzn. 2001. Asas-asas dan Susunan Hukum Adat. Jakarta: PT Pradnya Paramita.

Zainuddin Ali. 2009. Metode Penelitian Hukum. Jakarta: Sinar Grafika. 